\title{
ASPEK YURIDIS HAK ASUH ANAK AKIBAT PERCERAIAN ORANG TUA BERDASARKAN UNDANG-UNDANG PERKAWINAN DAN UNDANG-UNDANG PERLINDUNGAN ANAK (StudiKasusPerkara No. 098/Pdt.G/2017/PA.Gs)
}

\author{
Arkisman ${ }^{1}$, Ichsanul Hadi ${ }^{2}$ \\ 1. Dosen Program Studi Ilmu Hukum Fakultas Hukum Universitas Gresik \\ 2. Mahasiswa Program Studi Ilmu Hukum Fakultas Hukum Universitas Gresik
}

\begin{abstract}
ABSTRAK
Putusnya suatu perkawinan berdasarkan putusan pengadilan yang berkekuatan hukum tetap (inkracht van gewijsde), Masalahan yang diteliti adalah bagaimana alas an dalam pemberian hak asuh anak akibat perceraian orang tua berdasarkan Kompilasi Hukum Islam dan Undang-Undang Perlindungan Anak, penelitian hukum ini adalah penelitian hukum normative atau doktrinal. Penelitian hukum ini, dikonsepkan sebagai apa yang tertulis di dalam peraturan Perundangundangan (Low In Books) Penelitian dilakukan dengan cara meneliti bahan-bahan pustaka atau data sekunder yang terdiri dari bahan hukum primer, bahan hukum sekunder dan bahan hukum tertier. Gugatan perceraian yang dilakukanseorang suami dan isteri menimbulkan akibat terhadap anak-anaknya baik secara moril maupun materiil. Akibat dari perceraian yang pada umumnya sering timbul adalah tentang hadhanah atau yang bisa dikenal dengan Hak Asuh Anak. Apabila anak sudah mumayyiz (berumur 12 tahun) hendaklah diselidiki oleh yang berwajib siapakah di antara kedua orang tuanya yang lebih baik dan lebih cakap untuk mendidik anak tersebut.
\end{abstract}

Kata kunci : Hak Asuh, Nafkah, Perceraian.

\section{A. PENDAHULUAN}

\subsection{Latar Belakang}

Pasal 105 dan 156. Pasal 105 menentukan tentang pengasuhan anak pada dua keadaan:

1. Pertama, ketika anak masih dalam keadaan belum mumayyiz (kurang dari 12 tahun) pengasuhan anak ditetapkan kepada ibunya.

2. Kedua, ketika anak tersebut mumayyiz(usia 12 tahun ke atas) dapat diberikan hak kepada anak untuk memilih diasuh oleh ayat atau ibunya.
Pada Pasal 156 mengatur tentang Pengasuhan anak ketika ibu kandungnya meninggal dunia dengan memberikan urutan yang berhak mengasuh anak.Putusan pengadilan agama belum menjamin adanya pemenuhan hak-hak anak setelah terjadi perceraian. Pemegang hak hadanahbelum tentu bisa memenuhi sebagian atau seluruh hak-hak anak. Sehingga bisa jadi setelah adanya putusan Pengadilan Agama, pemegang hak hadanah tidak memenuhi hak-hak anak. Hal ini dikarenakan tidak adanya Undang-Undang yang mengatur tentang pengawasan hak-hak anak setelah terjadinya perceraian. 
Putusan Pengadilan Agama Gresik Nomor 098/Pdt.6/2017/PA.Gs memberikan putusan yang menetapkan bahwa ayah mendapat hadanah (hak pemeliharaan) terhadap anak. Hal tersebut menunjukkan bahwa ibu tidak mendapatkan hak asuh anak di bawah umur ketika terjadi perceraian.

Dengan demikian dalam pembuatan skripsi ini pembatasan masalah apa yang menjadi pertimbangan hakim memberikan kepada orang tua laki-laki (ayah) hak asuh pada anak di bawah umur, serta akibat hukum lain yang timbul dalam perceraian setelah putusan Pengadilan Agama Nomor: 098/Pdt.6/2017/PA.Gs.

\subsection{Rumusan Masalah}

1. Bagaimana alasan dalam pemberian hak asuh anak akibat perceraian orang tua berdasarkan Kompilasi Hukum Islam dan Undang - Undang Perlindungan Anak.

2. Bagaimanabentukpertimbangan hakim

dalammemutusperkaraperceraiantenta nghakasuhanakberdasarkanputusanPe ngadilan Agama Gresik Nomor 098/Pdt.6/2017/PA.Gs?

B. Tinjauan Pustaka

\subsection{Pengertian Perkawinan}

Dalam Pasal 1 Undang-Undang ini menyebutkan: "Perkawinan ialah ikatan lahir bathin antara seorang pria dengan seorang wanita sebagai suami isteri dengan tujuan membentuk keluarga (rumah tangga) yang bahagia dan kekal berdasarkan Ketuhanan Yang Maha Esa."1

${ }^{1}$ Subekti R, dan Tjitrosudibio R, terjemahan kitab Undang-undang hukum

\subsection{Akibat Putusnya Perkawinan} Menurut Pasal 209 KUHPer

menyebutkan berbagai alasan yang

dapat mengakibatkan perceraian,

terdiri atas:

1. Zinah atau overspel

2. Meninggalkan tempat tinggal bersama dengan itikad jahat.

3. Penghukuman dengan hukuman penjara lima tahun lamanya atau dengan hukuman yang lebih berat, yang diucapkan setelah perkawinan.

4. Melukai berat atau menganiaya, dilakukan oleh si suami atau si isteri terhadap isteri atau suaminya, yang demikian, sehingga membahayakan jiwa pihak yang dilukai atau dianiaya, atau sehingga mengakibatkan lukaluka yang membahayakan.

\subsection{Pengertian Hak Asuh Anak}

Anak mengandung banyak arti apalagi bila kata anak diikuti dengan kata lain misalnya anak turunan, anak kecil, anak sungai, anak negeri, dan lain sebagainya. ${ }^{2}$ Dalam Kitab Undang-Undang Hukum Perdata (BW) anak belum dewasa adalah mereka yang belum mencapai umur genap 21 tahun dan tidak lebih dahulu kawin, UU No 1 Tahun 1974 tidak lugas mengatur mengenai kapan seorang digolongkan sebagai anak, Secara tersirat dalam Pasal 6 Ayat 2 yang menyatakan bahwa syarat perkawinan bagi seorang yang belum

perdata, pasal 1, cet 28, Jakarta: Pradnya Paramita, 1996, hlm. 214.

${ }^{2}$ Hilman Hadikusuma, Bahasa Hukum Indonesia, Bandung: Alumni, 1992, hal. 83 . 
berumur 21 tahun harus mendapat ijin orang tuanya, Pasal 7 Ayat 1 UU No 1 Tahun 1974 menyatakan bahwa minimal usia anak dapat kawin pria 19 tahun dan wanita 16 tahun. Anak adalah putra putri kehidupan, masa depan bangsa dan negara. Oleh karena itu anak memerlukan pembinaan agar dapat berkembang mental dan spiritualnya secara maksimal. $^{3}$

\subsection{Akibat Perceraian Terhadap Anak}

akibat perceraian terhadap anak-anak yang masih di bawah umur ada dua bentuk, yaitu:

1. Menyangkut masalah perwalian;

2. Menyangkutmasalahmasalahkeuntungan yang menurutundangundangataumenurutperjanjiankawin.

Dalam menentukan hak asuh anak terdapat kesulitan dalam menentukan pihak mana yang telah dan mampu untuk menjalankan hak asuh anak tersebut.

\section{Metode Penelitian}

Dalam penyusunan skripsi ini, metode penelitian hukum adalah sebagai cara kerja ilmuwan yang salah satunya ditandai dengan penggunaan metode. Secara harfiah mula-mula metode diartikan sebagai suatu jalan yang harus ditempuh menjadi

${ }^{3}$ Darwan Prints dalam Iman Jauhari, Hak-hak Anak dalam Hukum Islam, Jakarta: Pustaka Bangsa Press, 2003, hal. 80. penyelidikan atau penelitian berlangsung menurut suatu rencana tertentu. ${ }^{4}$

\subsection{Tipe Penelitian}

Jenis penelitian penelitian hukum ini adalah penelitian hukum normatif atau doktrinal. Penelitian hukum normatif yang nama lainnya adalah penelitian hukum doktrinal yang disebut juga sebagai penelitian perpustakaan atau studi dokumen karena penelitian ini dilakukan atau ditujukan hanya pada peraturan-peraturan yang tertulis atau bahan-bahan hukum yang lain. ${ }^{5}$ Pada intinya penelitian yang dilakukan dengan cara meneliti bahan-bahan pustaka atau data sekunder yang terdiri dari bahan hukum primer, bahan hukum sekunder dan bahan hukum tertier. Ilmu hukum mempunyai karakter yang khas, yaitu sifatnya yang normatif, praktis dan preskriptif. ${ }^{6}$ Penelitian yang dikaji penulis dalam penelitian ini merupakan penelitian bersifat preskriptif, yang dimaksudkan untuk memberikan argumentasi atas hasil penelitian yang telah dilakukan.

\subsection{PendekatanPenelitian}

Di dalam melakukan penelitian hukum terdapat beberapa metode pendekatan, di antaranya adalah :

${ }^{4}$ Johny Ibrahim, Teori dan Metodologi Penelitian Hukum Normatif, Malang: Bayu Publishing, 2006, hlm. 26.

${ }^{5}$ Soerjono Soekanto, dan Sri Mamudji, Penelitian Hukum Normatif, Cetakan ke-8, Jakarta: PT. Raja Grafindo Persada, 2004, hlm. 14.

${ }^{6}$ Philipus M. Hadjon dan Tatiek Sri Djatmiati, Argumentasi Hukum, Yogyakarta: Gadjah Mada University Press, 2005, hlm. 1. 
1. Pendekatan

Undang-Undang

(statuteapproach)

Pendekatan

Undang-Undang

dilakukan dengan menelaah semua undangundang dan regulasi yang bersangkut-paut dengan isu hukum yangsedang ditangani.

2. Pendekatan kasus (case approach)

Dalam menggunakan pendekatan kasus, yang perlu dipahami oleh peneliti adalah ratio decidendi, yaitu alasan-alasan hukum yang digunakan oleh hakim untuk sampai kepada putusan-putusanya.

3. Pendekatanhistoris

(historicalapproach).

Metode pendekatan yuridis normatif, yaitu penelitian yang menitikberatkan kepada data sekunder atau data kepustakaan. ${ }^{7}$ Metode pendekatan dalam penelitian ini adalah pendekatan peraturan perundang-undangan (statue aproach). ${ }^{8}$

\subsection{BahanHukum}

\section{A. BahanHukum Primer}

Bahan hukum primer yaitu bahanbahan hukum yang mengikat. Adapun bahan hukum primer dari penelitian skripsi ini adalah

1. Undang-Undang Nomor 1 Tahun 1974

2. Undang-Undang Nomor 23 Tahun 2002

3. Kompilasi Hukum Islam ( Inpres Nomor 1 Tahun 1991.

${ }^{7}$ Ronny Hanitiyo, Metode Penelitian Hukum dan Juritmetri, Jakarta:Ghalia Indonesia, 1990, hlm.10

${ }^{8}$ Peter Mahmud Marzuki, 2008, Penelitian Hukum, Cet 2. Jakarta: Kencana, hlm 29
4. Kitab Undang-Undang Hukum Perdata.

\section{B. BahanHukumSekunder}

Bahan hukum sekunder merupakan bahan hukum yang bersifat membantu atau menunjang bahan hukum primer dalam penelitian skripsi ini dan akan memperjelas penjelasan di dalamnya. Di antaranya adalah buku-buku yang terkait dengan tema bahasan penelitian skripsi ini. ${ }^{9}$

\section{Hasil Penelitian dan Pebahasan}

\subsection{HAK ASUH ANAK AKIBAT PERCERAIANMENURUT UNDANG-UNDANG}

Masalah kewajiban orang tua terhadap anak setelah adanya perceraian diatur dalam Pasal 45 UU. Perkawinan, yang menyatakan bahwa:

1. Kedua orang tua wajib memelihara dan mendidik anak-anak mereka sebaik-baiknya.

2. Kewajiban orang tua yang dimaksud dalam Ayat (1) pasal ini berlaku sampai anak itu kawin atau dapat berdiri sendiri, kewajiban mana berlaku terus meskipun perkawinan antara kedua orang tua putus.

Perceraian tentunya akan membawa akibat-akibat hukum bagi kedua belah pihak dan juga terhadap anak-anak yang dilahirkan dalam perkawinan. Anak-anak tersebut harus hidup dalam suatu keluarga dengan orang tua tunggal baik dengan seorang ibu atau dengan seorang ayah saja. Dalam hal terjadi perceraian, tentunya yang sangat urgen untuk diperhatikan adalah persoalan biaya nafkah anak. Biaya nafkah anak ini

${ }^{9}$ Jhony Ibrahim, Op. Cit., hlm. 296. 
menyangkut semua hajat hidup dan keperluan yang berlaku menurut keadaan dan tempat seperti makanan, pakaian, tempat tinggal, biaya pendidikan dan lain sebagainya. Menurut Bahder Johan Nasution dan Sriwarjiyati "Bila terjadi pemutusan perkawinan karena perceraian, baik ibu maupun bapak tetap berkewajiban memelihara dan mendidik anak-anaknya semata-mata demi kepentingan anak-anak mereka, pengadilan akan memutuskan siapa yang akan menguasai anak tersebut". ${ }^{10}$ Biaya nafkah ini menjadi penting disebabkan anak harus tetap tumbuh dan berkembang sebagaimana mestinya dan memperoleh pendidikan yang layak demi masa depan anak di kemudian hari. Untuk itu, tentunya biaya nafkah anak setelah terjadinya perceraian perlu diatur dalam peraturan perundang-undangan. Jadi diperhatikan Pasal 24 huruf b Peraturan Pemerintah No.9 Tahun 1975 tentang Pelaksanaan Undang-Undang No. 1 Tahun tentang Perkawinan dan Pasal 78 huruf b Undang-Undang No.7 Tahun 1989 tentang Pengadilan Agama, kewajiban memberi biaya nafkah tersebut tidak hanya setelah terjadinya perceraian, akan tetapi juga dapat ditentukan selama proses perceraian berlangsung. Ketentuan tersebut mengatur bahwa selama berlangsungnya gugatan perceraian, atas permohonan penggugat dan tergugat, pengadilan dapat menentukan hal-

${ }^{10}$ Bahder Johan dan Sri Warjiyati, Hukum Perdata Islam, Komplikasi Peradilan Agama tentang Perkawinan, Waris, Wasiat, Hibah, Wakaf dan Shadaqah, Bandung: Madar Maju, 1997, hal.35. hal yang perlu untuk menjamin pemeliharaan dan pendidikan anak.

a. penghidupan dan/atau menemukan sesuatu kewajiban bagi mantan isteri.

Kemudian anak yang sudah mumayyiz berhak memiliki untuk mendapatkan hadanah dari ayah atau ibunya.

Dalam ketentuan Pasal 156 Instruksi Presiden Republik Nomor 1 Tahun 1991 tentang Kompilasi Hukum Islam menyatakan bahwa jika terjadi perceraian karena kehendak isteri (gugat cerai) biaya nafkah anak tetap dibebankan kepada orang tua lakilaki (ayah) sampai anak tersebut dewasa. Sehingga kalau diperhatikan pasal tersebut di atas bahwa hak hadanah terhadap anak yang belum mumayyiz (berusia 12 tahun) berada pada ibu. Sedangkan apabila anak sudah mumayyizx dapat diserahkan pada anak tersebut untuk memilih ikut ibu atau ayahnya.

2. Akibat Khulu'

Khulu' atau talak tebus adalah talak yang diucapkan oleh suami dengan pembayaran dari pihak isteri kepada suami.

Akibat perceraian lewat khulu', walaupun pada hakikatnya perceraian itu adalah atas kehendak isteri, namun mengenai biaya nafkah anak tetap menjadi tanggung jawab orang tua laki-laki (ayah). 


\section{Akibat $L i ' a n$}

Dalam Pasal 162 Kompilasi Hukum Islam (KHI) menjelaskan bahwa bilamana Li'an terjadi maka perkawinan itu putus untuk selamanya dan anak yang dikandung dinasalkan kepada ibunya. Sedangkan suaminya terbebas dari kewajiban memberi nafkah. Pewarisan hanya dapat terjadi antara anak dan ibunya saja.

\subsubsection{Hak dan Kewajiban Orang Tua serta Kekuasaannya}

Dalam Undang-Undang Nomor 1

Tahun 1974 tentang Perkawinan mengatur hak dan kewajiban antara orang tua dan anak antara lain ada beberapa hal:

Pertama; mengatur tentang kewajiban pemeliharaan dan pendidikan, bahwa kedua orang tua wajib memelihara dan mendidik anak-anak mereka dengan sebaik-baiknya. Dan kewajiban orang tua ini dalam Pasal 45 (1) Undang-Undang Perkawinan berlaku sampai anak-anaknya menikah atau dapat berdiri sendiri, kewajiban mana berlaku terus meskipun perkawinan di antara kedua orang tua putus.

Kedua; dalam Undang-Undang Perkawinan Pasal 46 mengatur yaitu kewajiban anak terhadap orang tuanya, yaitu anak wajib menghormati orang tua dan menaati kehendak mereka dengan baik; jika anak telah dewasa, ia wajib memelihara menurut kemampuannya, orang tua dan keluarga garis lurus ke atas, bila mereka itu memerlukan bantuannya.

Ketiga; yaitu mengatur tentang adanya keharusan anak diwakili orang tua dalam segala perbuatan hukum, seperti yang diatur dalam Pasal 47 Undang-Undang Perkawinan, menyebutkan anak yang belum mencapai umur 18 tahun (delapan belas tahun) atau belum pernah kawin ada di bawah kekuasaan orang tuanya selama tidak dicabut dari kekuasaannya.

Keempat; Orang tua tidak diperbolehkan memindahkan hak atau menggadaikan barang-barang tetap yang dimiliki anaknya yang belum berumur 18 (delapan belas) tahun atau belum pernah melangsungkan perkawinan, kecuali apabila kepentingan anak itu menghendaki.

Kelima; dalam Pasal 49 UndangUndang Perkawinan menyebutkan adanya kemungkinan pencabutan kekuasaan orang tua, yaitu bahwa salah satu atau kedua orang tua dapat dicabut kekuasaannya terhadap seorang anak atau lebih untuk waktu yang tertentu atas permintaan orang tua yang lain, keluarga anak dalam garis lurus ke atas dan saudara kandung yang telah dewasa atau pejabat yang berwenang dengan keputusan pengadilan dalam hal-hal:

a. Ia sangat melalaikan kewajibannya terhadap anaknya;

b. Ia berkelakuan buruk sekali.

Kemudian khusus di dalam hak dan kewajiban orang tua terhadap anak, mereka masih tetap berkewajiban untuk memberikan biaya pemeliharaan kepada anaknya.

\subsubsection{Akibat Perceraian Terhadap Anak}

Dalam Islam perceraian bukanlah suatu hal yang disukai, sesuai hadits Rasulullah yaitu "perkara halal yang sangat dibenci oleh Allah adalah thalaq/cerai", karena Islam mempertimbangkan 
pernikahan adalah sebuah akad/kontrak yang serius dan merupakan tanggung jawab dari kedua belah pihak (suami isteri) untuk menjalankan akad/kontrak dengan selalu mengingat Allah SWT dan mencari ridhoNya untuk menjalani kontrak tersebut dengan segenap kemampuan mereka. ${ }^{11}$

Namun dalam sebuah rumah tangga pastilah kerap terjadi konflik antara suami dan isteri dan berujung pada perceraian. Negara memberikan aturan yang cukup panjang untuk terjadinya perceraian. Di antaranya adanya aturan proses mediasi untuk mendamaikan pasangan suami isteri sebelum adanya persidangan di pengadilan dan cerai hanyalah sebagai jalan keluar bagi pasangan yang memang tidak bisa lagi didamaikan. ${ }^{12}$

Kemudian akibat perceraian terhadap anak-anak yang masih di bawah umur ada dua bentuk, yaitu:

4. Menyangkut masalah perwalian;

5. Menyangkut masalah-masalah keuntungan yang menurut undangundang atau menurut perjanjian kawin.

Dalam menentukan hak asuh anak terdapat kesulitan dalam menentukan pihak mana yang telah dan mampu untuk menjalankan hak asuh anak tersebut.

\subsection{Pengertian Hak Asuh Anak}

Dalam ajaran Islam, anak adalah amanat Allah kepada kedua orang tuanya,

\footnotetext{
${ }^{11}$ Adib Bahari, Tata Cara Gugatan Cerai Pembagian Harta Gono-Gini dan Hak Asuh Anak, Pustaka Yustitia, 2016, hal. 14.

${ }^{12}$ Ibid, hal. 15.
}

masyarakat, bangsa dan negara sebagai waris dari ajaran Islam, anak menerima setiap ukiran dan mengikuti semua pengarahan yang diberikan kepadanya ${ }^{13}$ Menurut Abdullah Bin Abdul Muhsin At Tuna sebagai mana dipaparkan oleh Abdul Rozak Husein dalam bukunya yang berjudul Hak Anak dalam Islam 'disebutkan bahwa masa kanak-kanak merupakan sebuah periode penaburan benih, pendirian tiang pancang, pembuatan pondasi yang dapat disebut dengan periode pembentukan. kepribadian dan karakter dari seorang manusia agar mereka kelak memiliki kemampuan dan kekuatan serta mampu berdiri tegar dalam meniti kehidupan. ${ }^{14}$ Anak berhak atas pelayanan untuk mengembangkan kemampuan dan kehidupan sosialnya, sesuai dengan kepribadian bangsa untuk menjadi warga negara yang baik anak berhak atas pemeliharaan dan perlindungan baik semasa dalam kandungan maupun sesudah dilahirkan. Anak berhak atas perlindungan terhadap lingkungan hidup yang dapat membahayakan atau menghambat pertumbuhan dan perkembangan yang wajar. ${ }^{15}$ Dalam pandangan Islam anak adalah titipan Allah SWT Kepada orang tua, masyarakat, bangsa, negara sebagai pewaris

${ }^{13}$ Safuddin Mujtaba dalam Iman Jauhari, Hak-Hak Anak dalam Hukum Islam, Jakarta: Pustaka Bangsa Press, hlm. 84.

${ }^{14}$ Abdul Rozak Husein, Hak Anak dalam Islam, Fikahati Aneka, 1992, hal. 13.

${ }^{15}$ Santy Dellyana, Wanita dan Anak di Mata Hukum, Yogyakarta: Liberty,, 1998, hal. 13 . 
dari ajaran islam, Pengertian ini memberikan hak atau melahirkan hak yang harus diakui, diyakini dan diamankan. ${ }^{16}$ Dalam Pasal 80 Ayat 4 Instruksi Presiden RI No. 1 Tahun 1991 tentang Kompilasi Hukum Islam ditegaskan pula bahwa suami menanggung biaya rumah tangga biaya perawatan dan biaya pengobatan bagi isteri dan anak sesuai dengan kemampuan penghasilannya selanjutnya, Dalam Pasal 81 ditegaskan bahwa suami wajib menyediakan tempat kediaman bagi isteri dan anak-anak dalam Pasal 98 tentang pemeliharaan anak, ditegaskan pula bahwa:

1. Batas usia anak yang mampu berdiri sendiri atau dewasa adalah 21 tahun sepanjang anak tersebut tidak cacat fisik maupun mental atau belum pernah melangsungkan perkawinan.

2. Orang tuanya mewakili anak tersebut mengenai segala perbuatan hukum di dalam maupun di luar pengadilan.

3. Pengadilan agama dapat menunjuk salah seorang kerabat terdekat yang mampu menunaikan kewajiban tersebut apabila kedua orang tuanya tidak mampu.

\subsubsection{Syarat-syarat Pemberian Hak}

\section{Asuh}

Merujuk pada fiqih bahwa yang disebut hadanah adalah pemeliharaan anak yang mengandung arti merawat dan mendidik anak yang belum mumayyiz. Merawat dan mendidik substansinya adalah

${ }^{16} \mathrm{M}$. Yahya Harahap, Hukum Perkawinan Nasional, Medan: Zahir Trading Co.,1975, hal. 123. karena yang bersangkutan tidak atau belum dapat memenuhi keperluan sendiri.

Para ulama fiqih menyatakan wajib hukumnya untuk merawat dan mendidik, namun berbeda pendapat di dalam persoalan hak hadanah atau biasa dengan hak asuh anak merupakan suatu kewajiban orang tua, baik dalam masa perkawinan atau bahkan perkawinan itu telah putus karena perceraian. Sesuai bunyi pasal-pasal yang tertuang dalam Undang-Undang Perkawinan maupun dalam Kompilasi Hukum Islam (KHI).

Kemudian dalam Kompilasi Hukum Islam (KHI) secara rinci mengatur tentang "pemeliharaan anak" dapat dilihat dalam Pasal 105 sampai dengan Pasal 112, dan mulai dari Pasal 107 sampai dengan Pasal 112 khusus mengatur tentang Perwalian. Dan pada Kompilasi Hukum Islam juga mengatur tentang Hadanah yaitu Pasal 98 KHI.

Dalam Pasal 98

1) Batas usia anak yang mampu berdiri sendiri atau dewasa adalah 21 tahun, sepanjang anak tersebut tidak bercacat fisik maupun mental atau belum pernah melangsungkan perkawinan.

2) Orang tua mewakili anak tersebut mengenai segala perbuatan hukum di dalam dan di luar pengadilan;

3) Pengadilan Agama dapat menunjuk salah seorang kerabat terdekat yang mampu menunaikan kewajiban tersebut apabila kedua orang tuanya tidak mampu. 
Pasal 105dalam hal terjadinya perceraian:

a. Pemeliharaan anak yang belum mumayyiz atau belum berumur 12 tahun adalah hak ibunya;

b. Pemeliharaan anak yang sudah mumayyiz diserahkan kepada anak untuk memilih di antara ayah atau ibunya sebagai pemegang hak pemeliharaan;

c. Biaya pemeliharaan ditanggung oleh ayahnya.

Pengaturan tentang kekuasaan orang tua terhadap anak pasca perceraian pada kriteria 12 tahun dalam KHI, karena usia ini anak dianggap telah akil baliq, sehingga pada usia belum memasuki usia 12 tahun, anak berada di bawah kekuasaan ibunya. Dan setelah melewati usia 12 tahun, anak diperbolehkan untuk menentukan pilihan sendiri, apakah ikut ibu atau ayah.

Berdasarkan ketentuan yang terdapat di dalam KHI maka dalam konteks kekuasaan orang tua terhadap anak pasca perceraian dapat dikemukakan beberapa hal sebagai berikut:

1. Kekuasaan orang tua terhadap anak pasca perceraian memiliki korelasi erat dengan validasi perkawinan, dan validasi perceraian dari orang tuanya.

2. Kekuasaan orang tua terhadap anak diungkapkan dengan istilah "pemeliharaan atau hadanah". Kenyataan ini sesuai dengan konsep kewajiban pengasuhan anak yang dikonstruksikan sebagai tidak terdapat pemisahan antara pengasuhan materiil dan non materiil.
3. Kekuasaan orang tua pasca perceraian terhadap anak pada dasarnya merupakan tanggung jawab dan kewajiban orang tua secara bersama-sama dengan mendidik dan memelihara anak, dengan ketentuan anak yang belum mumayyiz atau belum berusia 12 tahun berada dalam kekuasaan ibunya.

4. Kekuasaan orang tua pasca perceraian terhadap anak dapat diinvestasikan oleh Pengadilan Agama, dan Pengadilan Agama dapat memutuskan kepada siapa kekuasaan orang tua terhadap anak dijatuhkan.

Pasal- pasal KHI tentang hadanah tersebut menegaskan bahwa kewajiban pengasuhan material dan non material merupakan 2 hal yang tidak dapat dipisahkan. Lebih dari itu KHI malah menangani tugas-tugas yang harus diemban kedua orang tua kendatipun mereka berpisah, anak yang belum mumayyiz tetap di asuh oleh ibunya sedangkan pembiayaan menjadi tanggung jawab ayahnya.

Menurut UU Perkawinan, kewajiban orang tua terhadap anaknya pada dasarnya terbagi kepada 2 bagian yaitu pemeliharaan dan pendidikan. Kewajiban ini berlaku sampai anak tersebut kawin atau dapat berdiri sendiri walaupun perkawinan antara kedua orang tua itu telah putus.

\subsubsection{Dasar Hukum dan Prinsip Penentuan Hak Asuh Anak \\ Landasan Hukum tentang kewajiban} orang tua untuk memelihara dan mendidik anak-anak tersebut di dalam UU Perkawinan 
Pasal 45 Ayat 1 dan 2 di jelaskan tentang hak dan kewajiban antara orang tua dan anak:

1) Kedua orang tua wajib memelihara dan mendidik anak-anak mereka sebaik-baiknya.

2) Kewajiban orang tua yang dimaksud dalam Ayat (1) pasal ini berlakusampai anak itu kawin atau dapat berdiri sendiri kewajiban manaberlaku terus meskipun perkawinan antara kedua orang tua putus.

Dalam Pasal 41 UU Perkawinan akibat putusnya perkawinan karena perceraian ialah:

1. Baik ibu atau bapak tetap berkewajiban memelihara dan mendidik anak-anaknya, semata-mata berdasarkan kepentingan anak, bilamana ada perselisihan mengenai penguasaan anak-anak, Pengadilan memberi keputusannya.

2. Bapak bertanggung jawab atas semua biaya pemeliharaan dan pendidikan yang diperlukan anak itu, bilamana bapak dalam kenyataan tidak dapat memberi kewajiban tersebut, Pengadilan dapat menentukan bahwa ibu ikut memikul biaya tersebut.

3. Pengadilan dapat mewajibkan kepada bekas suami untuk memberikan biaya penghidupan dan menentukan sesuatu kewajiban bagi bekas isteri.

Pasal 49 Ayat (2) UU No.1 Tahun 1974 tentang Perkawinan, yakni: "Meskipun orang tua dicabut kekuasaannya, mereka masih tetap berkewajiban untuk memberi biaya pemeliharaan kepada anak tersebut". ${ }^{17}$

Dari bunyi ketentuan tersebut dapat kita simpulkan, baik anak itu di bawah pemeliharaan bapak atau ibu, maka yang menjamin jumlah biaya pemeliharaan dan pendidikan anak ialah bapak. Mengenai jumlah besarnya biaya ditentukan atas dasar kebutuhan anak, dan ketentuan tersebut diselaraskan dengan keadaan ekonomi orang tua.

KHI tidak berbeda dengan UU Perkawinan, di mana secara umum tanggung jawab orang tua terhadap anak tetap melekat meskipun telah bercerai. Oleh karena itu perlakuan terhadap anak adalah berdasarkan prinsip pemberian yang terbaik bagi anak.

Secara keseluruhan dapat dikatakan bahwa substansi dan semangat KHI tidak berbeda dengan UU Perkawinan. Kekuasaan orang tua terhadap anak pasca perceraian menurut ketentuan kedua UU adalah sejalan, mengingat makna kekuasaan orang tua terhadap anak sangat berkolerasi terhadap makna perkawinan dan perceraian sebagaimana diatur oleh KHI dan UU Perkawinan. Pemaknaan yang terdapat dalam kedua UU ini ternyata juga sejalan dengan pemaknaan perlindungan anak sebagaimana diatur di dalam UU Perlindungan anak, yaitu memberikan yang terbaik kepada anak. Dengan demikian, di dalam konteks hubungan antara KHI dan UU Perlindungan Anak, adalah memiliki tingkat harmonisasi yang baik.

${ }^{17}$ Adib Bahari, Prosedur Gugatan Cerai, hal. 164. 
Menurut UU Perkawinan, bahwa kewajiban orang tua terhadap anaknya pada dasarnya terbagi kepada 2 bagian, yaitu pemeliharaan dan pendidikan. Kewajiban ini berlaku terus sampai anak tersebut kawin atau dapat berdiri sendiri walaupun perkawinan antara kedua orang tua itu telah putus. yakni:

1. Dasar Kewajiban Pemeliharaan Anak Sebagai landasan Hukum tentang kewajiban orang tua untuk memelihara dan mendidik anak-anak tersebut di dalam UU Perkawinan Pasal 45 Pasal 1 dan 2.

2. Tujuan pemeliharaan anak, Kewajiban orang tua memelihara dan mendidik anak-anaknya adalah semata-mata berdasarkan kepentingan anak.

Adapun orang yang berhak melakukan pemeliharaan anak Dalam Pasal 41 (a) UU Perkawinan adalah Baik ibu atau bapak tetap berkewajiban memelihara dan mendidik anak-anaknya, semata-mata berdasarkan kepentingan anak, bilamana ada perselisihan mengenai penguasaan anakanak, Pengadilan memberi keputusan.

Pengadilanlah yang harus memilih dan menetapkan siapa di antara kedua orang tua yang sama-sama berhak akan melaksanakan pemeliharaan, untuk itu Pengadilan harus memeriksa dengan teliti siapakah di antara mereka yang lebih baik mengurus kepentingan anak. ${ }^{18}$

${ }^{18}$ M. Yahya Harahap SH, Hukum Perkawinan Nasional, (Medan: CV. Zahir Trading, 1975), 159.
Sedangkan tentang biaya pemeliharaan anak, biaya pemeliharaan dan pendidikan anak diatur dalam Pasal 41 (b) dan 49 Ayat 2 UU Perkawinan. Dalam Pasal 41 (b) UU Perkawinan. (b) Bapak yang bertanggung jawab atas semua biaya pemeliharaan dan pendidikan yang diperlukan anak itu, bilamana bapak dalam kenyataannya tidak dapat memberi kewajiban tersebut Pengadilan dapat menentukan bahwa ibu ikut memikul biaya tersebut.

Dari bunyi ketentuan tersebut dapat kita simpulkan, baik anak itu di bawah pemeliharaan bapak atau ibu, maka yang menjamin jumlah biaya pemeliharaan dan pendidikan anak ialah bapak. Mengenai jumlah besarnya biaya ditentukan atas dasar kebutuhan anak, dan ketentuan tersebut diselaraskan dengan keadaan ekonomi orang tua.

Dalam Pasal 49 Ayat 2 UU Perkawinan, meskipun orang tua dicabut kekuasaannya, mereka masih berkewajiban untuk memberi pemeliharaan kepada anak tersebut. Dari bunyi ketentuan tersebut dapat kita simpulkan, baik anak itu di bawah pemeliharaan bapak atau ibu, maka yang menjamin jumlah biaya pemeliharaan dan pendidikan anak ialah bapak. Mengenai jumlah besarnya biaya ditentukan atas dasar kebutuhan anak, dan ketentuan tersebut diselaraskan dengan keadaan ekonomi orang tua.

Hal ini memang patut sebagai lanjutan prinsip, bahwa bapak (suami) mempunyai kewajiban untuk memenuhi dan 
memberi segala kepentingan biaya yang diperlukan dalam kehidupan berumah tangga sesuai dengan kemampuannya, sebagaimana yang ditentukan Pasal 34 Ayat ....

Mengenai batas kewajiban pemeliharaan anak. Batas kewajiban Pemeliharaan dan pendidikan anak diatur pula, dalam Pasal 45 Ayat 2 UU Perkawinan: Kewajiban orang tua yang dimaksud dalam Ayat (1) pasal ini berlaku sampai anak itu kawin atau dapat berdiri sendiri kewajiban mana berlaku terus meskipun perkawinan antara kedua orang tua putus.

Jadi pokok-pokok batas kewajiban orang tua untuk memelihara dan mendidik anak-anaknya tidak ditentukan sampai batas umur tertentu, tetapi dilihat dari keadaan anak itu, Apabila anak dianggap telah dapat berdiri sendiri atau telah kawin, maka terlepaslah kewajiban orang tua untuk memelihara dan mendidiknya walaupun anak baru berumur 17 tahun, sebaliknya anak yang telah berumur 25 tahun tetapi belum mampu berdiri sendiri maka orang tua masih berkewajiban memelihara dan mendidik.

\subsection{PUTUSAN PERKARA HAK} ASUH ANAK.

Menimbang, bahwa sementara itu dalam Pasal 2 Undang-Undang Nomor 23 Tahun 2002 tentang Perlindungan Anak yang secara tegas menentukan bahwa penyelenggaraan perlindungan anak berasaskan Pancasila dan Undang-Undang Dasar 1945 serta prinsip-prinsip dasar Konvensi Hak-Hak Anak yang meliputi asas: (a) nondiskriminasi, (b) kepentingan yang terbaik bagi anak, (c) hak untuk hidup, kelangsungan hidup dan perkembangan, (d) penghargaan terhadap pendapat anak. Oleh karena itu Majelis berpendapat bahwa hak orang tua untuk memelihara anak harus diletakkan dalam kerangka mengedepankan kepentingan anak, atau dengan kata lain apabila diketemukan alasan kuat bahwa seorang anak lebih memungkinkan untuk tumbuh dan berkembang dalam pengasuhan bapak, maka hak pengasuhan anak / hadlanah dapat diletakkan dalam pemeliharaan / pengasuhan bapak;

Menimbang, bahwa kemudian dalam Pasal 3 Undang-Undang Nomor 23 Tahun 2002 dinyatakan bahwa "Perlindungan Anak bertujuan untuk menjamin terpenuhinya hak anak-anak agar dapat hidup, tumbuh, berkembang, dan berpartisipasi secara optimal sesuai dengan harkat dan martabat kemanusiaan, serta mendapat perlindungan dari kekerasan dan diskriminasi, demi terwujudnya anak Indonesia yang berkualitas, berakhlak mulia, dan sejahtera";

Menimbang, bahwa dari
pertimbangan hukum tersebut di atas, majelis berpendapat bahwa dasar dan orientasi dalam hadlanah/pemeliharaan anak adalah semata-mata demi kepentingan, kemaslahatan dan kemanfaatan bagi anak yang bersangkutan, sebaliknya adanya situasi dan kondisi pemegang hak hadlanah yang dapat merugikan kepentingan dan kesejahteraan serta membahayakan rohani/kejiwaan anak harus dihindarkan; 
Menimbang, bahwa berdasarkan pertimbangan hukum tersebut di atas, maka Majelis berkesimpulan bahwa selama ini anak bernama MRRP yang dalam asuhan Tergugat masih dapat tumbuh dan berkembang sesuai dengan kebutuhan asasi bagi ana4k dimaksud, oleh karena itu gugatan Penggugat tentang pemeliharaan anak/hadlanah terhadap anak bernama MRRP, harus dinyatakan ditolak;

Menimbang, bahwa meskipun gugatan Penggugat mengenai hak hadhonah terhadap anak bernama MRRP ditolak, namun Penggugat selaku ibu kandungnya memiliki hak yang sama dengan Tergugat dalam hal mencurahkan kasih sayangnya kepada anak tersebut dalam bentuk bertemu, bermain ataupun sekedar mengajak anak untuk jalan-jalan yang kesemuanya dimaksudkan untuk kepentingan anak itu sendiri;

Menimbang, bahwa sesuai ketentuan Pasal 89 Ayat 1 Undang-Undang Nomor 7 Tahun 1989 tentang peradilan agama, sebagaimana telah diubah dengan UndangUndang Nomor. 3 Tahun 2006 dan dengan Undang Undang Nomor 50 tahun 2009, biaya perkara dibebankan kepada Penggugat;

Mengingat, segala Pasal-pasal Perundang-Undangan yang berlaku dan hukum syar'i yang berkaitan dalam perkara ini;

\subsection{MENGADILI}

1. Mengabulkan gugatan Penggugat sebagian;

2. Menjatuhkan talak satu ba'in sughro
Tergugat (RPH bin S) terhadap Penggugat (AS binti TS );

3. Memerintahkan kepada Panitera Pengadilan Agama Gresik untuk mengirimkan salinan putusan ini yang telah memperoleh kekuatan hukum tetap kepada Pegawai Pencatat Nikah Kantor Urusan Agama Kecamatan Gresik Kabupaten Gresik, dan Pegawai Pencatat Nikah Kantor Urusan Agama Kecamatan Kebomas Kabupaten Gresik, untuk dicatat dalam daftar yang tersedia untuk itu;

4. Menolak gugatan Penggugat untuk selain dan selebihnya;

5. Membebankan kepada Penggugat untuk membayar biaya perkara ini sebesar Rp. 541.000,00 (lima ratus empat puluh satu ribu rupiah);

Demikian putusan dijatuhkan dalam sidang permusyawaratan Majelis Hakim pada hari Rabu tanggal 26 April 2017 Masehi. bertepatan dengan tanggal 1 Syakban 1438 Hijriyah, yang dibacakan dalam sidang terbuka untuk umum.

\subsection{Kesimpulan}

1. Gugatan hak asuh anak yang merupakan bagian dari perkara perceraian sebagai salah satu akibat hukum, maka bahwa anak yang belum mummayyiz diasuh oleh ibunya kecuali pertimbangan hakim untuk kepentingan si anak.

2. Bentuk pertimbangan hakim dalam memutus perkara perceraian tentang hak asuh anak berdasarkan Putusan 
Pengadilan Agama Gresik Nomor 098/Pdt.G/2017/PA.Gs adalah pasal 3 Undang-Undang Nomor 23 Tahun 2002 yang diubah dengan UndangUndang Nomor 35 tahun 2014 tentang Perlindungan Anak, yaitu bertujuan untuk menjamin terpenuhinya hak-hak anak agar dapat hidup, tumbuh, berkembang dan berpartisipasi secara optimal sesuai harkat dan martabat kemanusiaan, sehingga hadlanah/pemeliharaan anak tetap berada pada Tergugat dan kemudian dibuatkan oleh Pengadilan Tinggi Agama Surabaya.

\subsection{Saran}

1. Pembuat Undang-Undang dapat membuat Undang-Undang Perkawinan yang lebih jelas dan rinci serta bersifat futuristik, agar dapat mengakomodir segala persoalan hukum keluarga yang terjadi.

2. Baik untuk Pengadilan Negeri maupun Pengadilan Agama dapat memberikan solusi hukum kepada para pihak dalam hal hak asuh anak yang semata-mata demi terjaminnya pemenuhan kebutuhan anak sampai anak dewasa.

\section{DAFTAR PUSTAKA}

\section{A. Buku-buku}

Abdul Aziz Dahlan, Ensiklopedi Hukum Islam, Jakarta: Ikhtiar Baru Van Hoepe, 1999.

Abdul Manan, Penerapan Hukum Acara PerdataDi Lingkungan Peradilan Agama, Jakarta: Kencana, 2006.
Abdul Rozak Husein, Hak Anak dalam Islam, Fikahati Aneka, 1992.

Bahder Johan dan Sri Warjiyati, Hukum

Perdata Islam: Komplikasi

Peradilan Agama tentang

Perkawinan, Waris, Wasiat, Hibah, Wakaf dan Shadaqah, Bandung: Madar Maju, 1997.

Hilman Hadikusuma, Bahasa Hukum Indonesia, Bandung: Alumni, 1992.

Ibnu Hajar Al-Asqalani, Bulughul Maram, Hadis-hadis Pilihan tentang Islam, Bandung: CV Diponegoro, 1999.

Johny Ibrahim, Teori dan Metodologi Penelitian Hukum Normatif, Malang: Bayu Publlishing, 2006.

M. Hasballah Thaib, HukumKeluarga Dalam Syariat Islam, Medan:

Fakultas Hukum Universitas Dharmawangsa, 1993.

M. Yahya Harahap, Hukum Perkawinan Nasional, Medan: Zahir Trading Co., 1975.

Maulana Hassan Wadong, Advokasi dan Hukum Perlindungan Anak, Jakarta: PT. Grasindo, 2000.

Muhammad Syaifuddin, Hukum Perceraian, Jakarta: Sinar Grafika, 2014.

Peter Mahmud Marzuki, Penelitian Hukum, Cet ke-2. Jakarta: Kencana, 2008.

Philipus M. Hadjon dan Tatiek Sri Djatmiati, Argumentasi Hukum, Yogyakarta: Gadjah Mada University Press, 2005.

Ronny Hanitiyo, Metode Penelitian Hukum dan Juritmetri, Jakarta: Ghalia Indonesia, 1990. 
Soerjono Soekanto, dan Sri Mamudji, Penelitian Hukum Normatif, Cetakan ke-8, Jakarta: PT. Raja Grafindo Persada, 2004.

Subekti R, dan Tjitrosudibio R, Terjemahan Kitab Undang-undang Hukum Perdata, pasal 1, Cet 28, Jakarta: Pradnya Paramita, 1996.

William J. Goode, Sosiologi Keluarga, Jakarta: Sinar Grafika, 2004.

\section{B. Peraturan Perundang-undangan}

Kitab Undang-Undang Hukum Perdata.

Undang-Undang Nomor 1 Tahun 1974 tentang Perkawinan dan Peraturan Pelaksanaannya PP Nomor 9 Tahun 1975.

Undang-Undang Nomor 23 Tahun 2002 tentang Perlindungan Anak.

Instruksi Presiden Nomor 1 Tahun 1991 tentang Kompilasi Hukum Islam di Indonesia. 